\title{
Growth Evaluation of Listed Companies of the Agricultural Processing Industry in China
}

\author{
Xu ZheLing ${ }^{1}$, Wu Bizhi',*, \\ ${ }^{1}$ International Business Department, Fuzhou Melbourne Polytechnic \\ ${ }^{2}$ State Key Laboratory of Marine Environmental Science, Xiamen University
}

\begin{abstract}
By 2019, agricultural products processing and production enterprises have grown into an large industry for farmers to make a better living and for consumers to enjoy safer food. More importantly, it has become a vital supporting force to safeguard China's growing modernization. However, the agricultural Processing industry is in an era of great challenges and opportunities. Therefore, this study is dedicated to provide a unique and sustainable-development perspective of this issue. A comprehensive scoring system is constructed to obtain the outstanding listed agricultural product processing enterprises with excellent scores and ratings. The excellent characteristics of high-growth listed companies are summarized to give suggestions and inspirations to sustainable economy of the agricultural processing industry in China.
\end{abstract}

\section{Background}

In the social-economic conference hosted by president Xi Jinping on 24 August 2020 in Zhongnanhai, he gave an important speech on prioritizing the circulation of the national economy to structure a new blueprint of China's economic development. This new blueprint is a strategic decision vital to the reconstruction of China's international cooperative and competitive advantage.

According to the previous deployment of the China government, 2020 is the year of decisive victory in poverty alleviation. The China government has put forward specific ideas for this decisive victory especially agricultural products processing and production enterprises which are at the core of agriculture have great potential in elevating China's development. Industrial activities in rural areas includes more than traditional crop plantation and cattle breeding with newly adopted modern day technology. There are innovated rural industries include agricultural processing focusing on agricultural products processing and circulation, tourism and leisure centers in developed rural areas, rural tertiary and telecommunication industry. Above all, agricultural processing industry is not only the largest but also the most relevant and most profitable industry for farmers.

By 2019, agricultural products processing and production enterprises have grown into a large industry for farmers to make a better living and for consumers to enjoy safer food. More importantly, it has become a vital supporting force to safeguard China's growing modernization of agriculture and rural development with a scale of 81,000 enterprises and with an annual gross operating revenue of 22 trillion. However, China still face great challenges in strengthening its modern agricultural systems and industries when its agricultural processing is at the peril of becoming apple of sodium if no further measures were taken to tackle the conundrum and dilemma of clashed interests between growing demand from industrialization and industrial restructuring. It is now a decisive moment to make an urgent quest for acceleration of agricultural processing development. Therefore, this paper will be dedicated to provide an unique perspective of this issue and explore a new pathway through researching the developmental potential of the listed agricultural processing corporations in an effort to contribute to the current literature to achieve more effective poverty reduction outcomes and to win the war against poverty.

Moreover, a future worth looking forward to is a future of safer food, healthier national economy circulation. And this vision is vital to China's next developmental stage.

\section{Literature review}

The current scholarships on the listed agricultural processing companies have been mainly conducted by Chinese researchers. Liu and Wang (2015) found that This research applies the factor analysis methodology into the examination of the financial positions of the listed companies in China's feed industry by scrutinizing its liquidity, profitability, operational capability and potentiality. By doing so, they fractionate the performance appraisal into into sub-categorical differences and indicative factors thus further contribute to this area of scholarship ${ }^{[1]}$. Ji Xiaoxian, Gu Wenlin (2019) "A Research on the Competitiveness Evaluation of Listed Agricultural Products Processing Companies", using China's A-share listed agricultural product

* Corresponding author: wubizhi@xmu.edu.cn 
processing companies as the research sample, adopting the catastrophe progression method as the main research method, with the entropy method and PEARSON correlation coefficient analysis as Auxiliary research method. Therefore, step by step their calculation lead to the acquisition of the evaluation of of the competitiveness of the sampled enterprises with further horizontal and vertical comparative analysis for a more comprehensive and in-depth examination ${ }^{[2]}$.

Liu Chao, Hu Baogui (2018) in "Evaluation of the Listed Companies in the Feed industry" took a sample of 21 feed listed companies and their data in 2016 as the research object, adopting factor analysis to construct a comprehensive evaluation system for the growth of listed feed companies. The growth of the chosen sample of listed companies in feed industry is ranked, compared and evaluated critically in accordance with this system. However, their evaluation system overlooks the companies capability modules of enterprise innovation and $R \& D$ investments which are indispensable parts of corporation development and performance. Therefore, this paper aspires to fill this gap in the current literature by adding an extra capability module of corporation innovation into the current evaluation system. Meanwhile this paper will also critically draw on previous scholars' research and findings thus further construct systematic quantitative analysis to evaluate the listed companies of agricultural product processing enterprises at the same time exploring an innovative path of development for the agricultural sector of China's economy ${ }^{[3]}$.

\subsection{Sample and Indicator Selection}

Till September 30, 2020, according to Shenyin Wanguo Research Industry Classification Standard (2014 edition) of listed companies, this study select 16 listed companies (excluding 2 ST companies which refer to the domestic listed companies have been special treatment of the stock, but also delisting risk warning.). The main business of the research sample is agricultural processing. Data is from Oriental Wealth Choice data terminals, the choice of samples can reflect the basic information of agricultural products processing industry and conform to the principle of growth evaluation purpose. ${ }^{[4]}$

On the one hand, listed agricultural processing are selected because compared with other agricultural enterprises, listed agricultural processing companies have established relatively strict financial system and the data of listed companies are transparent and open. On the other hand, listed agricultural product processing companies represent the long-term development trend of enterprises in the agricultural sector and even the agricultural industry, and are highly representative.

\subsection{Construction of Evaluation Indicators system}

\begin{tabular}{|c|c|c|c|}
\hline $\begin{array}{l}\text { First-level } \\
\text { indicator }\end{array}$ & $\begin{array}{l}\text { Second-level } \\
\text { Indicator }\end{array}$ & $\begin{array}{l}\text { Indicator } \\
\text { CODE }\end{array}$ & Indicator Significance \\
\hline \multirow[t]{3}{*}{$\begin{array}{l}\text { Profitability } \\
\text { (A) }\end{array}$} & Gross Profit Margin & A1 & $\begin{array}{l}\text { Gross Profit Margin is the percentage of Gross } \\
\text { Profit relative to sales (or operating income) }\end{array}$ \\
\hline & Net Interest Rate & $\mathrm{A} 2$ & $\begin{array}{l}\text { Net profit margin is the percentage of net income } \\
\text { from operations as a percentage of net sales, or as a } \\
\text { percentage of invested capital. This percentage } \\
\text { gives a comprehensive indication of the operating } \\
\text { efficiency of a business or industry }\end{array}$ \\
\hline & Return 0n Equity & A3 & $\begin{array}{l}\text { The Return on Equity (ROE) is the percentage ratio } \\
\text { of a company's after-tax profit divided by its net } \\
\text { assets. It reflects the Return level of shareholders' } \\
\text { Equity and is used to measure the efficiency of a } \\
\text { company in using its own capital }\end{array}$ \\
\hline \multirow[t]{2}{*}{$\begin{array}{l}\text { Capacity } \\
(\mathbf{M})\end{array}$} & Total market value & M1 & $\begin{array}{l}\text { Total market value refers to the total amount of } \\
\text { capital stock multiplied by the current share price } \\
\text { during a certain period of time }\end{array}$ \\
\hline & $\begin{array}{l}\text { Circulation } \text { Market } \\
\text { Value }\end{array}$ & M2 & $\begin{array}{l}\text { Current market value refers to the number of } \\
\text { tradable shares that can be traded within a certain } \\
\text { period of time multiplied by the current share price } \\
\text { at that time to obtain the total value of the current } \\
\text { shares }\end{array}$ \\
\hline \multirow[t]{2}{*}{ Quality（R） } & Revenue & $\mathrm{R} 1$ & $\begin{array}{l}\text { Revenue is the income obtained from the main } \\
\text { business or other businesses }\end{array}$ \\
\hline & Deposit received & $\mathrm{R} 2$ & $\begin{array}{l}\text { Deposit received refers to the amount of the } \\
\text { purchase Deposit or part of the payment in advance } \\
\text { received by an enterprise from the buyer. It is } \\
\text { directly related to the income scale and order } \\
\text { turnover rate. }\end{array}$ \\
\hline
\end{tabular}




\begin{tabular}{|l|l|l|l|}
\hline $\begin{array}{l}\text { Development } \\
\text { (I) }\end{array}$ & Net profit I1(\%) & I1 & $\begin{array}{l}\text { Net profit growth rate is the current net profit } \\
\text { compared the growth range of net profit on period } \\
\text { of the enterprise. The bigger the indicator value, the } \\
\text { stronger the enterprise profitability. }\end{array}$ \\
\hline & $\begin{array}{l}\text { Operating revenue } \\
\text { I2(\%) }\end{array}$ & I2 & $\begin{array}{l}\text { The year-on-year growth rate of operating income } \\
\text { is the standard to test whether the earning ability of } \\
\text { listed companies has improved in the past year. The } \\
\text { year-on-year growth of operating income indicates } \\
\text { that the earning ability of a company has } \\
\text { strengthened in the previous year. }\end{array}$ \\
\hline $\begin{array}{l}\text { Innovation } \\
\text { (C) }\end{array}$ & R\&D expense C1 & C1 & $\begin{array}{l}\text { R \& D expenses refer to the expenses paid for the } \\
\text { research and development of a certain project }\end{array}$ \\
\hline Ratio C2 (\%) & investment & C2 & $\begin{array}{l}\text { Technology investment ratio refers to the ratio } \\
\text { between the current year's science and technology } \\
\text { expenditure (including expenditure on research and } \\
\text { development, technological transformation and } \\
\text { innovation) and the current year's operating income. } \\
\text { It reflects the enterprise's investment in scientific } \\
\text { and technological progress and can reflect the } \\
\text { enterprise's development potential to some extent }\end{array}$ \\
\hline
\end{tabular}

According to the development status and industrial attributes of China's listed agricultural product processing companies, in order to objectively reflect the growth level of listed enterprises, the growth evaluation indicators system of listed agricultural product processing companies was established. The system selected 5 first-level indicators and 10 second-level indicators. Profitability (A) selects Gross interest rate (A1), net interest rate (A2) and return on equity (A3). Capacity (M) selects total market value (M1) and Current market value (M2); Quality (R) selects Revenue (R1) and receivables (R2) in advance. Development (I) selects the year-on-year growth of net profit I1(\%) and operating revenue $\mathrm{I} 2(\%)$; Innovation $\mathrm{C}$ selects $\mathrm{R} \& \mathrm{~d}$ expense $\mathrm{C} 1$ and $\mathrm{R} \& \mathrm{D}$ investment ratio $\mathrm{C} 2(\%)$.

\section{The Research Methodology}

In this study, MATLAB2019 software is used to complete the factor analysis operation.

Factor analysis is a kind of multivariate statistical analysis method, which is based on the study of the internal dependence of the index correlation matrix, and sums up some variables with overlapping information and complicated relations into a few uncorrelated comprehensive factors.

Factor analysis is used to explore the growth of listed companies in the agricultural product processing sector, it is necessary to find common factors that influence and determine the development, profit and scale of these listed companies, and these common factors are unobservable hidden variables. Factor analysis can well mine the common implicit variables.

Factor analysis uses the idea of dimension reduction to decompose the original variables into two parts, one is a linear combination of a few common factors, the other is a special factor unique to variables. The purpose of factor analysis of variables is to study what common factors they have, which are special factors, and what role these factors play in variable analysis.

In this study, it is assumed that the five one-level indicators $(A \backslash M \backslash R \backslash C \backslash I \backslash C)$ are given the same weight, the regression coefficient is weighted average. A comprehensive scoring system is constructed to obtain the outstanding listed agricultural product processing enterprises with excellent scores and ratings. The excellent characteristics of high-growth listed companies are summarized to give Suggestions and inspirations to the agricultural processing industry in China.

Suppose the sample population is $\mathrm{x}=(\mathrm{x} 1, \mathrm{X} 2$ The mean value of the sample is $u=(\mathrm{U} 1$, U2 Then the general model of factor analysis is as follows:

$$
\mathrm{x}=\mathrm{u}+\mathrm{Af}+\mathrm{e}
$$

Where $\mathrm{A}$ is the factor loading matrix, $\mathrm{F}$ is the common factor vector, and $\mathrm{E}$ is the special factor vector, where the common factors, the special factors, and the common factors and the special shadows are all unrelated.

After a reasonable explanation of the common factor, the scores of each common factor corresponding to each sample should be required to facilitate further understanding of the category of samples. The common methods of factor scoring include weighted least square method and regression method. In MATLAB, the command format used is:

$$
\text { [lambda,psi,T,stats,F] }=\text { factor } \operatorname{an}(\mathrm{X}, \mathrm{m})
$$

$\mathrm{X}$ is a matrix with $\mathrm{n}$ rows and d columns, one sample for each row, one variable for each column. Lambda in the return parameter is the load matrix of the factor model containing $\mathrm{m}$ common factors; Psi is the maximum likelihood estimate of the special variance. $\mathrm{T}$ is the rotation matrix, stats is a structural variable containing the model test information, including the maximum value 
of the logarithmic likelihood function, the error degree of freedom, the approximate chi-square test statistics and the $p$ value of the test; $F$ is the score matrix of $n$ rows and $\mathrm{M}$ columns of the factor, and each row corresponds to the score of $\mathrm{m}$ common factors of a sample.

Table 2: Score and ranking of factors of listed agricultural processing companies

\begin{tabular}{|c|c|c|c|c|c|c|c|c|c|c|c|c|}
\hline \multirow[t]{2}{*}{ Stock No. } & \multirow[t]{2}{*}{ Company } & \multicolumn{2}{|c|}{ Profitability (A) } & \multicolumn{2}{|c|}{ Development (I) } & \multicolumn{2}{|c|}{ Capacity Scale(M) } & \multicolumn{2}{|c|}{ Quality (R ) } & \multicolumn{2}{|c|}{ Innovation (c) } & \multirow{2}{*}{$\begin{array}{c}\text { Total } \\
\text { Ranking }\end{array}$} \\
\hline & & Score & Ranking & Score & Ranking & Score & Ranking & Score & Ranking & Score & Ranking & \\
\hline $000505 . S Z$ & JINLIANG KONGGU & -0.712862432 & 12 & -0.11694097 & 11 & 0.352227008 & 5 & 1.123237903 & 2 & -0.256512623 & 8 & 6 \\
\hline 000930.SZ & ZHONGLIANG KEJI & 0.969718861 & 2 & 0.729550227 & 2 & 0.483301307 & 4 & 0.051671464 & 10 & -1.56240989 & 15 & 4 \\
\hline 002286.SZ & BAO LIN GBAO & -0.28558501 & 8 & 0.262352175 & 6 & -0.836193459 & 12 & 0.926759604 & 3 & -1.051740432 & 12 & 11 \\
\hline 002852.SZ & DAO DAO QUAN & -0.563840688 & 11 & 0.200677315 & 7 & -0.314816645 & 8 & 0.568815497 & 6 & -0.304879372 & 9 & 10 \\
\hline 300138.SZ & CHENGUANG SHENGWU & 0.141494757 & 4 & 0.648104894 & 4 & -0.879968221 & 13 & 0.668392743 & 4 & -0.822958387 & 10 & 8 \\
\hline 300175.SZ & LANGYUAN GUFEN & -0.326677356 & 9 & 0.407520352 & 5 & -0.804126799 & 11 & -1.386401622 & 13 & 0.70801486 & 6 & 13 \\
\hline 300268.SZ & JIAWO GUFEN & 0.227072548 & 3 & -3.248264747 & 15 & -0.304444136 & 7 & -0.848161861 & 12 & -1.085341807 & 13 & 15 \\
\hline $300829 . \mathrm{SZ}$ & JINDAN KEJI & -0.908144161 & 15 & -0.003709186 & 10 & -1.265513568 & 15 & 1.287461279 & 1 & 1.613872001 & 1 & 5 \\
\hline 600127.SH & JINJIAN MIYE & -0.729913108 & 14 & -0.483318497 & 14 & 0.146050868 & 6 & 0.349353054 & 9 & 0.863392738 & 5 & 7 \\
\hline 600191.SH & HUAZI SHIYE & -0.719507422 & 13 & 0.043280896 & 8 & -0.356688955 & 9 & -1.76489377 & 15 & 1.542385842 & 2 & 12 \\
\hline 600251.SH & GUANNONG GUFEN & 0.128875386 & 5 & 1.406495356 & 1 & 1.045985731 & 3 & -1.753894445 & 14 & -1.157499423 & 14 & 9 \\
\hline 600298.SH & ANQI JIAOMU & 3.252240528 & 1 & 0.025170544 & 9 & -0.437039231 & 10 & 0.35439107 & 8 & 1.205428218 & 4 & 1 \\
\hline 600737.SH & ZHONGLIANG TANGYE & -0.074630366 & 7 & -0.118875101 & 12 & 1.929200095 & 2 & 0.586532997 & 5 & 0.132381949 & 7 & 3 \\
\hline 600873.SH & MEIHUA SHENGWU & -0.389888688 & 10 & -0.403041796 & 13 & 2.262896786 & 1 & 0.381902952 & 7 & 1.207401986 & 3 & 2 \\
\hline 600962.SH & GUOTOU ZHONGLU & -0.008352848 & 6 & 0.650998538 & 3 & -1.020870781 & 14 & -0.545166866 & 11 & -1.031535659 & 11 & 14 \\
\hline
\end{tabular}

\section{Profitability (A): Angel Yeast (600298.sh) ranked} No.1.

In 2019, Angel Yeast's (600298.SH) sales revenue exceeded 7.6 billion yuan, an increase of more than 40 times compared with 184 million yuan in the year of listing 2000. The total annual production of yeast reached 250,000 tons, an increase of 11.5 times compared with 20,000 tons in 2001. In 2019, the company achieved revenue of 7.653 billion yuan, with a year-on-year increase of $14.47 \%$. The net profit was 940 million yuan, with a year-on-year increase of $5.23 \%$. In 2019 , the gross profit margin of the company's yeast products reached $40.92 \%, 1.85$ percentage points higher than that in 2018. Angel Yeast is the world's largest yeast-extract (YE) producers, the company's capacity is about 78,000 tons, accounting for $25 \%$ of the global production capacity. The China domestic market share is more than $60 \%$ and has established the market leading position. In the future, Angel Yeast (600298.SH) is expected to continue to enjoy the industry expansion dividend.

Development capacity (I): Guannong Gufen (600252.sh) ranked No.1.

In 2019, Guan Nong Realized a total operating revenue of 3.257 billion yuan, with a year-on-year growth of $49.76 \%$, and a net profit of 170 million yuan with a year-on-year growth of $81.75 \%$.In 2019, Guan Nong adhered to the supply-side structural reform as the main line, made great efforts to promote the "Double hundred Actions" of the reform of state-owned assets and enterprises, and constantly solved various development problems, which effectively guaranteed the healthy and rapid development of the economy. The company has

\subsection{The Empirical Result Analysis}

made new breakthroughs in key areas of reform. The company started equity incentive, 118 core employees would receive 7 million shares of equity incentive, which makes Guan Nong Stock become the first listed company in the XPCC to enter the substantive stage of equity incentive.

Capacity Scale (M): Meihua Shengwu (600873.SH) ranked No.1

The total assets and operating income of a company are important indicators to reflect the scale of a company. Meihua Biotechnology Group Co., Ltd. is the world's leading provider of amino acid nutrition and health solutions. Meihua provides various amino acid products and solutions for many well-known customers in more than 100 countries and regions in the world.

Meihua Group has the most complete and longest industrial chain and supporting facilities in the biological fermentation industry. Through the whole series of research, production, supply and marketing services, it flexibly meets the differentiated needs of different customers around the world and the pursuit of rapid innovation, and focuses on creating a high-end industrial platform of biological fermentation and biopharmaceutical. Strong industrialization ability is also reflected in part of the production line can be flexible adjustment, low-cost adjustment of the product portfolio, timely response to market demand. The steady increase in performance and market value enables the enterprise to maintain steady and sustainable growth.

Earnings quality (R): Jindan Technology (300829.SZ) ranked NO.1

In 2019, the revenue and gross profit of Jindan Technology are mainly from lactic acid business, accounting for $66 \%$ and $59 \%$ respectively. In addition, saccharification residue, a by-product of corn primary 
processing in lactic acid production process, accounts for $14 \%$ of the gross profit, higher than the proportion of its business. According to the data of the past five years, the business structure of the company is relatively stable, and the proportion of the revenue and gross profit of the three business sectors, lactate, lactate and sacking residue, basically remains stable. Rigid growth of food and beverage demand, feed prohibition and resistance to increase the amount of acidifier, although the revenue growth slowed down in 2019 , but the total revenue reached a new high of 880 million yuan; In the same period, the fluctuation of net profit has increased, which has shown an obvious trend in the past three years. In 2019, the full-year net profit was 110 million yuan. In the first quarter of 2020, the company realized a revenue of 200 million yuan, with a year-on-year growth of 5.9\%, and the net profit attributable to mother was 4,000 yuan, with a year-on-year growth of $48.5 \%$, mainly due to the increase in sales of lactic acid and derivatives and the improvement of product structure.

Innovation (C): Jindan Technology (300829.SZ) ranked No.1.

Jindan technology (300829.SZ) promotes technological innovation and expands R\&D platform. Jindan has been engaged in a series of lactic acid product research and development for many years. Moreover, Jindan has excellent new product plan, meanwhile undertook major industry technology development projects, agricultural and sideline products deep-processing project and a series of other technology research and development projects. The company actively carries out research on lactic acid in new application fields, invests actively in r\&d personnel, R\&D projects and so on, and the R\&D expenditure proportion is always higher than the industry average level. At the same time, the company's patent portfolio is growing steadily.

Table3: The comprehensive regression analysis results

\begin{tabular}{cccc}
\hline Grade and grade reference & \multicolumn{2}{c}{$\begin{array}{c}\text { Number and proportion of } \\
\text { companies }\end{array}$} \\
\hline Grade reference & Grade & Number & Proportion \\
\hline$>0.6$ & A & 2 & $13.33 \%$ \\
$0.3 \sim 0.6$ & B & 5 & $33.30 \%$ \\
$-0.3 \sim 0.3$ & C & 7 & $46.70 \%$ \\
$-0.3>$ & D & 1 & $6.67 \%$ \\
\hline
\end{tabular}

A comprehensive regression analysis was carried out for the listed companies in the sample. Angel Yeast(600298.SH) and Meihua Shengwu (600873.SH) were rated as $\mathrm{A}$, which reflected the high growth potential of the whole sample, accounting for $13.3 \%$ of the total sample. The distribution was at $-0.3 \sim 0.3$, with a ratio as high as $46.7 \%$. On the whole, there is a big difference in growth, the number of enterprises with better growth is small, the growth of most agricultural products processing listed enterprises is average, and the overall growth level of listed companies needs to be improved.

\subsection{Conclusions and Suggestions}

The agricultural processing industry in China develops rapidly, effectively promoting transformation and added-value of agricultural products. However, due to the short development time and insufficient innovation and development capacity, the number of listed companies in agricultural subdivision in the China capital market is still not large, and non-listed agricultural products processing enterprises are facing various problems like financing difficulty.

In order to accelerate the growth level of listed agricultural product processing companies, to enhance the market competitiveness and to promote the healthy, sustainable development of agricultural processing industry, the following company strategy and policy suggestions are put forward:

\subsubsection{Optimize industrial chain structure of the company}

Firstly, companies plan as a whole to promote comprehensive utilization of deep and raw processing of agricultural products. Further, companies gradually form coordinated development of related processing and special raw material production, warehousing logistics (including the cold-chain logistics) and organic link upstream and downstream industries.

In the future, a sustainable agricultural processing Industrial Ecology involve nutrition and health, leisure, tourism, education, culture, health preservation and the organic combination of the rural industry, such as electronic commerce. The government should regularly monitor and analyze the distribution of production capacity for deep processing and comprehensive utilization of large agricultural products, guide the reduction of overcapacity in the transfer of production capacity and accelerate the construction of capacity in shortage, and improve Optimize industrial chain layout.

\subsubsection{Adjust the strategic layout according to its own characteristics}

The intensive processing capacity of agricultural products should be distributed to grain production function zones, major agricultural production protection zones, advantage zones for featured agricultural products, modern agricultural demonstration zones. Agricultural products should be converted into value-added services locally. In order to save energy, reduce emissions, save money, and reduce consumption, and improve the market competitiveness of refined and refined products, processing parks, industrial clusters, and logistics hubs would be built. Through PPP and other means, more private capital would be leveraged to increase investment in processing parks, cluster areas and infrastructure and public service systems. Relying on big data, cloud computing and other information means, the formation of a new mode of production development should be accelerated and led by the deep processing of varieties, production customization and production and marketing. 


\subsubsection{Increase green fiscal support and improve financial services}

Appropriately increase support for scientific research into the fine processing technology and equipment for agricultural products are necessary. Financial institutions should continue to innovate the products and services, increase credit support for leading enterprises in agricultural industrialization, guide guarantee institutions to increase the guarantee credit, loans and bond issuance for enterprises, and establish multi-level risk mitigation measures and risk sharing mechanisms. Qualified agricultural products intensive processing enterprises are supported in applying for issuing special bonds for the integrated development of rural industries, and applying for listing, neeQ-Listed and other listing financing.

\subsubsection{Increase investment in R\&D to seek technological innovation}

Listed agricultural processing companies give full play to their advantages in the capital market, promote technological innovation and expand r\&d platforms. They should pay attention to the cultivation of talents in research teams, and make use of various new and high technologies to create new forms of business with great potential for development. Enterprises which specialized in ensuring stable growth and be represented by the new and high technology to the field of agricultural management penetration, diffusion, blur boundaries between agriculture and secondary and tertiary industries, and to provide technical support for the development of modern agriculture and the path, achieving industrial upgrading, catalytic generate new formats.

\subsubsection{Focus on the improvement of brands quality and realize the sustainable upgrade of the agricultural processing Industry}

The agricultural processing Industry in China has made considerable progress. However the industry is still large but not strong, and there is still a large gap compared with world's advanced level. There are few well-known Agricultural products brands, especially Chinese and national brands with international influence and competitiveness..$^{[5]}$

Enterprises should set quality and integrity as the core of the brand concept, constantly excavate the connotation of brand culture, enhance the brand added value and soft power. Enterprises are encouraged to make full use of platforms such as official media, social media and end-consumer groups to accelerate the overall upgrading of brand, production and sales capabilities. Appropriate marketing agencies are welcome to participate in enterprise brand cultivation activities, to provide enterprises with forward-looking brand cultivation models that conform to the characteristics of the development of The Times, and accelerate the cultivation of a number of brands and enterprises that can display the confident quality image of "Made in China" and "China service".

\section{Reference}

1. Caihua Liu and Xiaoxue Wang (2015) Financial performance evaluation of listed companies in the feed industry based on factor analysis

2. Ji Xiaoxian, Gu Wenlin (2019) "Research on Competitiveness Evaluation of Listed Agricultural Product Processing Enterprises"

3. Liu Chao, Hu Guijin (2018) "Research on Growth Evaluation of Feed Listed Companies"

4. Sun Chunxiao li Chunyan(2014) Zhijiang College of Zhejiang University of Technology " Performance evaluation of Assets divestiture of Chinese listed companies" 2014 International Conference on e-Education, e-Business and Information Management (ICEEIM 2014)

5. Chen Yongan, Liu Hanmin, Qi Yu(2020) School of Management, Jinan University (2020) "Compliance and Corporate performance: Facilitating or inhibiting? -- Measurement and empirical test based on compliance index of listed companies" On Stock Market Guide. Issue 10, 